\title{
Influence of different polyethylene packaging on shelf life of tuberose (Polianthes tuberosa Linn.) loose flowers
}

\begin{abstract}
Tuberose is an important commercial loose flower crop because of its fragrant flowers which can be utilized in many ways. Tuberose loose flowers retain their freshness only for a few days in ordinary condition. Packaging technology concentrated on longer period of storage of loose flowers would certainly be beneficial. In view of rapidly increasing demand of loose flowers of tuberose and need for extending their postharvest quality, the present study was initiated. The experiments included ten treatments namely, three thickness of polyethylene bags (dimention $20 \times 25 \mathrm{~cm}$ ) i.e., 50,75 and 100 micron with three levels of ventilated rates i.e., $0 \%, 1 \%$ and $2 \%$ and control. Three cultivars of Single petalled tuberose namely, Mexican Single, Prajwal and Sikkim Selection were chosen for the experimentation. Fully developed mature florets (loose flowers) were plucked from growing plants and brought to the laboratory for experimentation. The statistically analysed data revealed that the higher (in cvs Mexican Single, Prajwal and Sikkim Selection, respectively) floret diameter $(4.66,5.00$ and $5.58 \mathrm{~mm})$, floret weight $(0.62,0.70$ and $0.84 \mathrm{~g})$, relative water content $(84.03,82.97$ and $88.86 \%)$, membrane stability index $(76.90,77.32$ and $79.81 \%$ ), total sample weight $(178.86,169.80$ and $175.93 \mathrm{~g})$ and shelf life $(5,6$ and 5 day) were recorded with loose flowers stored in 100 micron thick polyethylene bags without ventilation. The control treatment (when florets were kept in open plastic basket) recorded the lower value for above mentioned parameters. The lower physiological loss in weight $(0.66,1.75$ and $2.38 \mathrm{~g}$, respectively) was obtained in florets packed in 100 micron thick polyethylene bags without ventilation. On the other hand, the higher physiological loss in weight $(94.98,95.90$ and $96.14 \mathrm{~g}$, respectively) was reported in control treatment. The higher freshness index of florets ( 5 for all cultivars) was recorded when florets were packed in 50,75 and 100 micron thick polyethylene bags with $0 \%$ ventilation, followed by (for all cultivars) packaging of florets in 50,75 and 100 micron thick polyethylene bags with $1 \%$ ventilation. However, the lower freshness index ( 1 for all cultivars) was obtained in florets packed in 50,75 and 100 micron thick polyethylene bags with $2 \%$ ventilation and also in control treatment.
\end{abstract}

Keywords: loose flower, packaging, Polianthes tuberosa, polyethylene, shelf life, tuberose, ventilation
Volume I Issue 6 - 2018

\author{
NKL Khongwir,' MC Singh, ${ }^{2}$ Krishan P \\ Singh,' Ajay Arora ${ }^{3}$ \\ 'Division of Floriculture and Landscaping, India \\ ${ }^{2}$ Centre for Protected Cultivation Technology, India \\ ${ }^{3}$ Division of Plant Physiology, ICAR-Indian Agricultural Research \\ Institute, India
}

Correspondence: MC Singh, Department of Centre for Protected Cultivation Technology, New Delhi, India Emailmansingh@gmail.com

Received: April 20, 2018 | Published: November 27, 2018

\section{Introduction}

Tuberose (Polianthes tuberosa Linn.) occupies a prime position among commercial flower crops because of its highly fragrant flowers which can be used in various ways. It belongs to the family Agavaceae and originated in Mexico. It is one of the most popular commercial flower crops in tropical and sub-tropical areas of the world including India. It is also grown for garden decoration, in kitchen gardens, pots, beds, borders, etc. It is a perennial herbaceous plant usually produce flowering spikes throughout the year but it blooms profusely during summer and rainy seasons. Waxy white flowering spikes of single as well as double petalled cultivars of tuberose impregnate the surroundings with their sweet lingering fragrance and are in great demand for use in different forms of loose and cut flowers and extraction of concrete Singh et al., ${ }^{1}$ Tuberose is adorned with vernacular names like Rajanigandha (Hindi), Gulsaboo (Urdu), Nelasampengi (Telugu), Sugandharaja (Kannada), Nishigandha (Marathi), tuberoos (Dutch), tubereuse ( French),tuberose (English, German) and Nargo (Spanish).Apart from huge demand of tuberose flowers and essential oils in domestic markets, it has a great demand for export also. Packaging is a tool for controlling flower quality in distribution chain. Apart from preventing mechanical damage, the package serves as a barrier between the condition inside and outside the package. It protects the flowers from unfavourable outside condition and enables a micro climate to develop inside the package Nowak et al., ${ }^{2}$ The main principles of packaging towards long storage life and keeping quality are to lower their rate of transpiration, respiration and cell division during transport and storage. Since flower are delicate and highly perishable, they need great attention through suitable technology in packaging to keep them fresh to consumers satisfaction Bhattacharjee., ${ }^{3}$ Tuberose loose flowers retain their freshness only for a few days in ordinary condition. Due to short span of life of harvested loose flowers of tuberose, growers often face the problem of storage. Karuppaian et al., ${ }^{4}$ reported that packaging of loose flowers of Jasminum sambac in 200 micron thick polyethylene bag was significant in extending their shelf life. Any packaging technology focussed on longer period of storage of loose flowers of tuberose would definitely be beneficial. Keeping in view of the increasing demand for loose flowers of tuberose and need for enhancing their postharvest life, the present experiments were undertaken to study the 
effect of different polyethylene (PE) packaging on extending shelf life of loose flowers of three cultivars of tuberose.

\section{Materials and methods}

Selected tuberose cultivars were cultivated at the Research Farm of ICAR- Directorate of Floricultural Research, IARI Campus, New Delhi. New Delhi is located at $28^{\circ} 35^{\mathrm{I}} \mathrm{N}$ latitude, $77^{\circ} 12^{\mathrm{I}} \mathrm{E}$ longitude and an altitude of $228.16 \mathrm{~m}$ above the mean sea level. Uniform package of practices were followed to grow healthy crop Singh et al. ${ }^{1}$ The experiments were carried out in the laboratory of the Division of Plant Physiology and Centre for Protected Cultivation Technology, ICAR-Indian Agricultural Research Institute, New Delhi, during 2014 and 2015. Three cultivars of Single petalled tuberose namely, Mexican Single, Prajwal and Sikkim Selection were selected for this study. Fully developed mature florets (loose flowers) were hand-plucked from flowering spikes of growing plants early in the morning (6 to $8 \mathrm{a} . \mathrm{m}$.), collected in muslin cloth bags and brought to the laboratory for experimentation. The experiments included 10 treatments namely, three thickness of polyethylene bags i.e., 50, 75 and 100 micron gauge with three levels of ventilated rates i.e., $0 \%, 1 \%$ and $2 \%$ and a control (without treatment). In control treatment loose flowers were kept in plastic basket (dimention $22.5 \mathrm{~cm} \times 18.0 \mathrm{~cm}$ ). The experiments were carried out in completely randomized block design with three replications. For each cultivar fully developed mature florets of uniform size and shape and free from insect and disease incidence were separated out at each harvest. The dimension of each polyethylene bag was $20 \times 25 \mathrm{~cm}$ for all treatments and each treatment contained $180 \mathrm{~g}$ quantum of florets. The experiments were conducted under ambient laboratory condition.

\section{During the course of experimentation, data on the following parameters were recorded time to time}

The details of treatments employed during this study are mentioned below (Table 1)

Initial florets diameter $(\mathrm{mm})$ was measured of 10 randomly selected florets and mean was calculated. The individual floret diameter $(\mathrm{mm})$ was measured by digital varnier calliper. The relative water content (RWC) was measured by taking $100 \mathrm{~g}$ of fresh floret strips and putting in into a test tube containing double distilled water. Fresh weight and treatment weight of these petals were noted after they were dried into hot air oven. The formula for calculating relative water content is given below:

$$
\text { Relative Water Content }(R W C)=\frac{\text { Fresh weight }- \text { Dry weight }}{\text { Treatment weight }- \text { Dry weight }} \times 100
$$

The membrane stability index (MSI) was determined according to the methods of Premchand et al., ${ }^{5}$ as modified by Sairam, ${ }^{6}$ Florets strips $(10 \mathrm{~g})$ of uniform size were taken in a test tube containing 100 $\mathrm{ml}$ of double distilled water in two sets. Test tube in one set were kept at $4^{\circ} \mathrm{C}$ in a water bath for 30 minute and electrical conductivity of the water containing sample was measured $(\mathrm{C} 1)$ using a conductivity bridge. Test tube in the other set incubated at $100^{\circ} \mathrm{C}$ in the boiling water bath for 15 minute and their electrical conductivity was measured as above (C2), was calculated using formula given below:

$$
\text { Membrane Stability Index }(M S I)=\left(1-C_{1} / C_{2}\right) \times 100
$$

The final weight of total sample of florets was taken at the termination of shelf life of florets. The initial fresh weight of florets was recorded before initiating the experiments and final weight was recorded at the termination of shelf life stage and was expressed in percentage. It was calculated using the following formula:

$$
\begin{aligned}
& \text { Final weight }(g)-\text { Initial weight }(g) \\
& \text { Weight change }=------------x 100 \\
& \text { Initial weight }(g)
\end{aligned}
$$

Table I Treatments employed during this study

$\begin{array}{ll}\text { SI. No. Treatment details } & \text { Control ( without packaging ) } \\ \text { I } & \text { Packaging of florets in } 50 \text { micron thick polyethylene bag with } 0 \% \text { ventilation } \\ 3 & \text { Packaging of florets in } 50 \text { micron thick polyethylene bag with I \% ventilation } \\ 4 & \text { Packaging of florets in } 50 \text { micron thick polyethylene bag with } 2 \% \text { ventilation } \\ 5 & \text { Packaging of florets in } 75 \text { micron thick polyethylene bag with } 1 \% \text { ventilation } \\ 6 & \text { Packaging of florets in } 75 \text { micron thick polyethylene bag with } 2 \% \text { ventilation } \\ 7 & \text { Packaging of florets in } 100 \text { micron thick polyethylene bag with } 0 \% \text { ventilation } \\ 9 & \\ 10 & \end{array}$


For calculating of fresh weight of the florets, observations were recorded at an interval of two days starting from the first day of experimentation till these florets were presentable (depending upon the shelf life of loose flowers). Loose flowers were assigned A, B and $\mathrm{C}$ grades which were given points as shown below(Table2):

Table 2 Loose flowers were assigned A, B and C grades

\begin{tabular}{lll}
\hline Freshness/Appearance & Grade & Point \\
\hline Florets with original bright colour & A & 5 \\
Florets with moderately faded from original colour & B & 3 \\
Florets severely faded from original colour & C & I \\
\hline
\end{tabular}

Shelf life of florets was observed when time taken for development of necrotic symptoms was recorded and shelf life was determined as number of days taken for placing for the loose flowers till wilting and fading of petals of these loose flowers. The recorded data were statistically analysed for the completely randomized block design viz., computation of mean, standard error and critical difference (CD) value $\mathrm{P}=0.05$ were carried out using SAS 9.4 package.

\section{Results and discussion}

Packaging of tuberose florets of cvs. Mexican Single, Prajwal and Sikkim Selection in polyethylene (PE) bags of different thickness without ventilation in general recovered significantly higher floret diameter, floret weight, relative water content, membrane stability index, total sample weight, freshness index of florets and shelf life and the lower physiological loss in weight when compared with control treatment.

\section{Floret diameter $(\mathrm{mm})$}

Table 3 indicated that in cv. Mexican Single, the higher diameter of florets $(4.63 \mathrm{~mm})$ was observed on florets kept in 100 micron thick PE bags having $\%$ ventilation and remained statistically at par with other treatments except for florets packed in 50micron thick PE bags with $2 \%$ ventilation $(4.06 \mathrm{~mm})$ followed by control treatment $(3.48 \mathrm{~mm})$. It is evident from Table 4 that in cv. Prajwal the higher value for floret diameter $(5.00 \mathrm{~mm})$ was measured in florets kept in 100 micron thick PE bags with $0 \%$ ventilation and remained statistically at par with treatments packaging of florets in 75 micron thick PE bags without ventilation $(4.98 \mathrm{~mm})$ and with $1 \%$ ventilation $(4.64 \mathrm{~mm})$. Table 5 indicated that in cv. Sikkim Selection significantly higher floret diameter $(5.58 \mathrm{~mm})$ was recorded by florets kept in 100 micron thick PE bags having $0 \%$ ventilation followed by 75 micron thick PE packaging without ventilation $(5.56 \mathrm{~mm})$. In control treatment the minimum floret diameter $(3.12 \mathrm{~mm})$ was measured. Madaiah \& Reddy ${ }^{7}$ recommended packaging of tuberose cv. Single florets in 300 guage thickness PE bags without ventilation under ambient condition. Nagaraja et al., ${ }^{8}$ suggested packaging of loose flowers of tuberose cv. Single in 200 micron thick PE without ventilation under ambient condition.

\section{Floret weight (g)}

It is clear from the Table 3 that in cv. Mexican Single, the higher weight of individual floret $(0.62 \mathrm{~g})$ was recorded by the florets kept in 100 micron thick PE bags with $0 \%$ ventilation and remained statistically at par with treatments of packaging of florets in 75 micron thick PE bags with or without ventilation and also 50 micron thick PE bags without ventilation. The lowest floret weight was measured in control treatment $(0.31 \mathrm{~g})$. Table 4 revealed that in cv. Prajwal, the higher floret weight was recorded when florets were stored in 100micron thick PE bags without ventilation which remained statistically at par except packaging of florets in 75 and 50 micron thick PE with ventilation and control treatment. Table 5 indicated that in cv. Sikkim Selection, the higher floret weight $(0.84 \mathrm{~g})$ was recorded when florets were kept in 100 micron thick PE bags without ventilation and remained statistically at par with other treatments except for the florets stored in open baskets as control being the lowest $(0.61 \mathrm{~g})$. These results are in close agreement with findings of Nirmala \& Reddy ${ }^{9}$ and Karuppaiah et al., ${ }^{4}$ in Jasminum sambac.

\section{Relative water content (\%)}

Data presented in Table 3 indicated that in cv. Mexican Single, florets kept in 100micron thick PE bags without ventilation exhibited the maximum water content $(84.03 \%)$ and remained statistically at par with florets stored in 50micron thick PE packaging without ventilation $(80.17 \%)$. The lowest relative water content was recorded in control treatment $(60.23 \%)$ followed by packaging of loose flowers in $2 \%$ ventilation in 75 micron thick (67.52 \%) and 50micron thick $(67.95 \%)$ PE bags. Table 2 indicated that in cv. Prajwal the highest relative water content $(82.79 \%)$ was recorded in loose flowers stored in 100 micron thick PE bags with no ventilation and remained statistically at par with loose flowers kept in 75 micron thick PE bags $(81.04 \%)$. However, the lowest relative water content $(55.01 \%)$ was found in control treatment. Data presented in Table 3 revealed that in cv. Sikkim Selection, the higher relative water content $(88.86 \%)$ was recorded in florets kept in 100 micron thick PE bags without ventilation followed by loose flowers kept in 75 micron thick PE bags without ventilation $(82.77 \%)$. However, the lowest relative water content $(57.43 \%)$ was recorded in control treatment. Our results are in accordance with the findings of Nagaraja et al., ${ }^{8}$ in packaging of loose flowers of Jasminum smabac under 200 micron thick PE bags with the minimum ventilation.

\section{Membrane stability index (\%)}

Table 3 revealed that in cv. Mexican Single, the higher (79.90\%) membrane stability index (MSI) was recorded by the florets kept in 100micron thick PE bags without ventilation, followed by florets stored in 50 and 75 micron thick PE bags without ventilation. The lowest (66.73\%) MSI was recorded in loose flowers stored in baskets (control). Table 2 indicated that in cv. Prajwal the higher (77.32\%) MSI was obtained when loose flowers were kept in 100 micron thick PE bags with $0 \%$ ventilation followed by loose flowers stored without ventilation of 75 micron thick $(75.84 \%)$ and 50 micron thick $(75.36 \%)$ PE bags. The lowest value $(60.76 \%)$ of MSI was obtained in control treatment. Table 3 revealed that in cv. Sikkim Selection, the higher value $(79.81 \%)$ of MSI was retained by loose flowers stored in 100 micron thick PE bags with $0 \%$ ventilation. Loose flowers kept in control treatment recorded the lowest value $(60.00 \%)$ of MSI. Our results are in close agreements with findings of Kumari et al., ${ }^{10}$ in tuberose (Polianthes tuberosa L.) flowers and Thamaraiselvi et al.," in jasmine (Jasminum sambac Ait.) flowers. 
Table 3 Response of polyethylene packaging and rate of ventilation on postharvest quality parameters in tuberose cv. Mexican Single

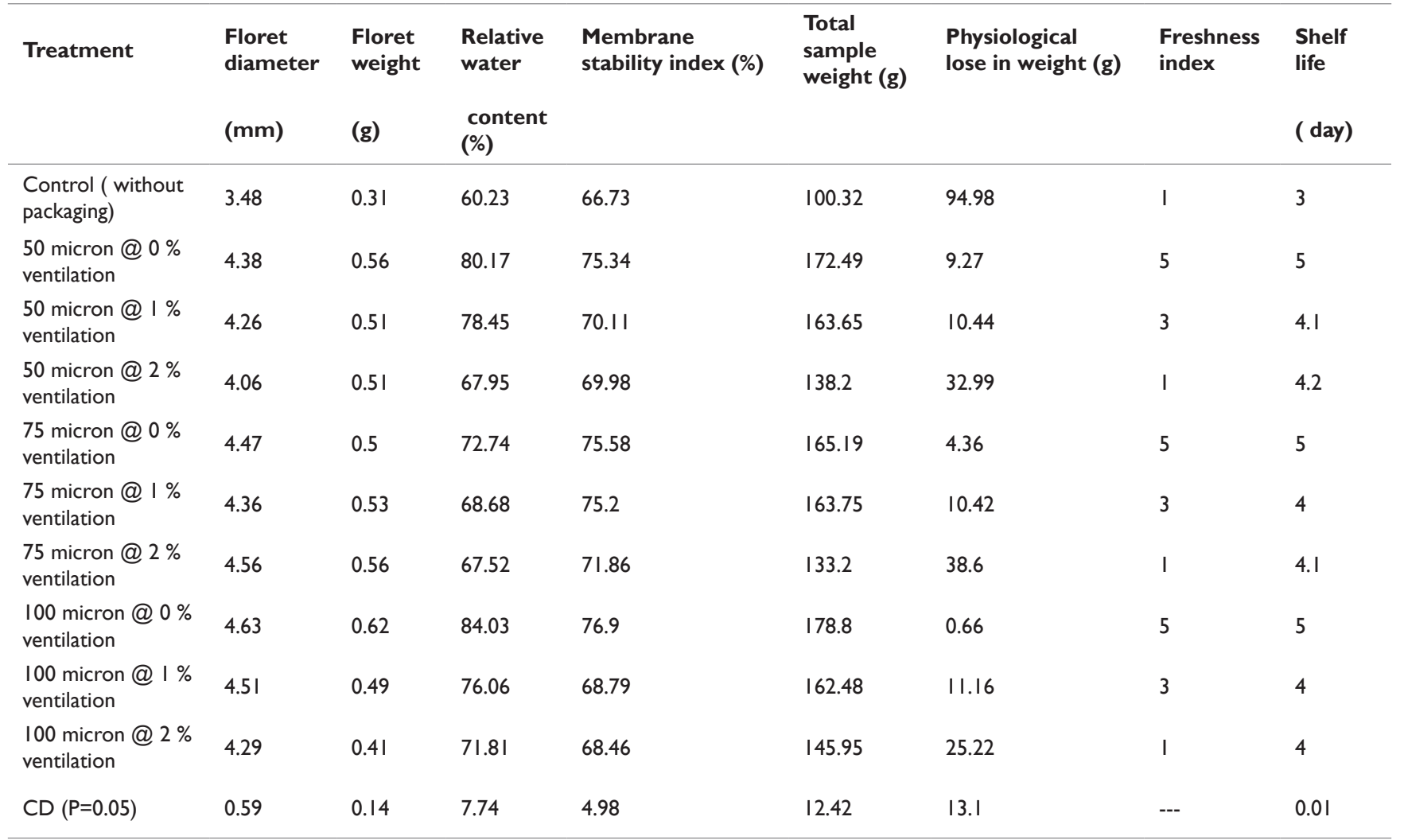

Note: Freshness index is expressed as grades, where grade $\mathrm{A}$ denotes 5 points, $\mathrm{B} 3$ points and $\mathrm{Cl}$ point.

Table 4 Response of polyethylene packaging and rate of ventilation on postharvest quality parameters in tuberose cv. Prajwal

\begin{tabular}{|c|c|c|c|c|c|c|c|c|}
\hline Treatment & $\begin{array}{l}\text { Floret } \\
\text { diameter } \\
(\mathrm{mm})\end{array}$ & $\begin{array}{l}\text { Floret } \\
\text { weight } \\
\text { (g) }\end{array}$ & $\begin{array}{l}\text { Relative } \\
\text { water } \\
\text { content (\%) }\end{array}$ & $\begin{array}{l}\text { Membrane } \\
\text { stability index } \\
(\%)\end{array}$ & $\begin{array}{l}\text { Total sample } \\
\text { weight }(\mathrm{g})\end{array}$ & $\begin{array}{l}\text { Physiological lose in } \\
\text { weight }(\mathrm{g})\end{array}$ & $\begin{array}{l}\text { Freshness } \\
\text { index }\end{array}$ & $\begin{array}{l}\text { Shelf } \\
\text { life } \\
\text { (day) }\end{array}$ \\
\hline $\begin{array}{l}\text { Control (without } \\
\text { packaging) }\end{array}$ & 3.8 & 0.54 & 55.01 & 60.76 & 120.93 & 95.9 & I & 3 \\
\hline $\begin{array}{l}50 \text { micron @ } 0 \% \\
\text { ventilation }\end{array}$ & 4.45 & 0.66 & 72.98 & 75.36 & | 48.75 & 4.54 & 5 & 5 \\
\hline $\begin{array}{l}50 \text { micron @ I \% } \\
\text { ventilation }\end{array}$ & 4.42 & 0.64 & 63.96 & 70.97 & 136.2 & 20.96 & 3 & 4 \\
\hline $\begin{array}{l}50 \text { micron @ } 2 \text { \% } \\
\text { ventilation }\end{array}$ & 4.56 & 0.62 & 68.42 & 70.46 & 124.72 & 44.89 & I & 4 \\
\hline $\begin{array}{l}75 \text { micron @ } 0 \% \\
\text { ventilation }\end{array}$ & 4.98 & 0.65 & 81.04 & 75.84 & 156.99 & 4.37 & 5 & 5 \\
\hline $\begin{array}{l}75 \text { micron @ I \% } \\
\text { ventilation }\end{array}$ & 4.64 & 0.69 & 69.14 & 74.96 & $|46.9|$ & 22.5 & 3 & 4 \\
\hline $\begin{array}{l}75 \text { micron @ } 2 \text { \% } \\
\text { ventilation }\end{array}$ & 4.49 & 0.67 & 68.01 & 73.7 & 134.58 & 40.18 & I & 4 \\
\hline $\begin{array}{l}100 \text { micron @ } 0 \\
\% \text { ventilation }\end{array}$ & 5 & 0.7 & 82.97 & 77.32 & 169.98 & 1.75 & 5 & 6 \\
\hline $\begin{array}{l}100 \text { micron @ I } \\
\% \text { ventilation }\end{array}$ & 4.68 & 0.67 & 76.07 & 73.4 & | 44.07 & $|4.0|$ & 3 & 5 \\
\hline $\begin{array}{l}100 \text { micron @ } 2 \\
\% \text { ventilation }\end{array}$ & 4.1 & 0.68 & 72.1 & 68.6 & $|27.2|$ & 34.99 & I & 5 \\
\hline$C D(P=0.05)$ & 0.8 & 0.11 & 12.78 & 7.98 & 16.87 & 19.89 & -- & 0.01 \\
\hline
\end{tabular}

Note: Freshness index is expressed as grades, where grade $\mathrm{A}$ denotes 5 points, $\mathrm{B} 3$ points and $\mathrm{Cl}$ point 
Table 5 Response of polyethylene packaging and rate of ventilation on postharvest parameters in tuberose cv. Sikkim Selection

\begin{tabular}{|c|c|c|c|c|c|c|c|c|}
\hline Treatment & $\begin{array}{l}\text { Floret } \\
\text { diameter }\end{array}$ & $\begin{array}{l}\text { Floret } \\
\text { weight }\end{array}$ & $\begin{array}{l}\text { Relative } \\
\text { water content } \\
(\%)\end{array}$ & $\begin{array}{l}\text { Membrane } \\
\text { stability index (\%) }\end{array}$ & $\begin{array}{l}\text { Total sample } \\
\text { weight }(\mathrm{g})\end{array}$ & $\begin{array}{l}\text { Physiological } \\
\text { lose in } \\
\text { weight (g) }\end{array}$ & $\begin{array}{l}\text { Freshness } \\
\text { index }\end{array}$ & $\begin{array}{l}\text { Shelf } \\
\text { life }\end{array}$ \\
\hline & $(\mathrm{mm})$ & (g) & & & & & & ( day) \\
\hline $\begin{array}{l}\text { Control } \\
\text { (without } \\
\text { packaging) }\end{array}$ & 3.12 & 0.61 & 57.43 & 60 & 99.71 & 96.14 & I & 3 \\
\hline $\begin{array}{l}50 \text { micron @ } 0 \\
\% \text { ventilation }\end{array}$ & 4.39 & 0.82 & 74.88 & 77.24 & 128.18 & 4.35 & 5 & 5 \\
\hline $\begin{array}{l}50 \text { micron @ I } \\
\% \text { ventilation }\end{array}$ & 5.3 & 0.76 & 72.83 & 74.36 & $|55.1|$ & 17.08 & 3 & 4.1 \\
\hline $\begin{array}{l}50 \text { micron @ } 2 \\
\% \text { ventilation }\end{array}$ & 4.46 & 0.75 & 69.75 & 70.95 & 134.96 & 34.55 & I & 4 \\
\hline $\begin{array}{l}75 \text { micron @ } 0 \\
\% \text { ventilation }\end{array}$ & 5.16 & 0.82 & 82.77 & 74.97 & 159.5 & 6.74 & 5 & 5 \\
\hline $\begin{array}{l}75 \text { micron @ I } \\
\% \text { ventilation }\end{array}$ & 5.58 & 0.82 & 67.76 & 74.45 & 139.45 & 34.54 & 3 & 4 \\
\hline $\begin{array}{l}75 \text { micron @ } 2 \\
\% \text { ventilation }\end{array}$ & 5.39 & 0.82 & 78.94 & 67.95 & 172.74 & 49.56 & I & 4 \\
\hline $\begin{array}{l}100 \text { micron @ } \\
0 \% \text { ventilation }\end{array}$ & 5.56 & 0.84 & 88.86 & 79.81 & 175.93 & 2.38 & 5 & 5 \\
\hline $\begin{array}{l}100 \text { micron @ } \\
\text { I \% ventilation }\end{array}$ & 5.23 & 0.75 & 77.3 & 68.75 & I56.37 & 15.42 & 3 & 4.1 \\
\hline $\begin{array}{l}100 \text { micron @ } \\
2 \% \text { ventilation }\end{array}$ & 5.39 & 0.82 & 78.93 & 74.01 & | 44.36 & 25.39 & I & 4 \\
\hline$C D(P=0.05)$ & $\mid .21$ & 0.13 & 9.82 & 6.82 & 15.32 & 19.3 & -- & 0.01 \\
\hline
\end{tabular}

Note: Freshness index is expressed as grades, where grade $\mathrm{A}$ denotes 5 points, $\mathrm{B} 3$ points and $\mathrm{Cl}$ point

\section{Total sample weight (g)}

Data presented in Table 3 revealed that in cv. Mexican Single the higher total sample weight $(178.80 \mathrm{~g})$ was recorded when loose flowers were kept in 100micron thick PE bags without ventilation, closely followed $(172.49 \mathrm{~g})$ by packaging of loose flowers in 50 micron thick PE bags with $0 \%$ ventilation. However, the lower total sample weight $(100.32 \mathrm{~g})$ was recorded in control treatment. It is evident from Table 4 that in cv. Prajwal, the higher total sample weight (169.98g) was recorded when flowers were stored in 100micron thick PE bags without ventilation, followed by $(156.99 \mathrm{~g})$ packaging of loose flowers in 75 micron thick PE bags with $0 \%$ ventilation. The minimum total sample weight of loose flowers $(120.99 \mathrm{~g})$ was obtained in control treatment. Table 3 indicated that in cv. Sikkim Selection, the higher value of total sample weight $(175.93 \mathrm{~g})$ was recorded in loose flowers stored in 100micron thick PE bags without ventilation, closely followed $(172.74 \mathrm{~g})$ by packaging in 50micron thick PE bags without ventilation. The minimum total sample weight $(99.71 \mathrm{~g})$ was recorded in control treatment. The total sample weight loss may be associated with the rate of respiration that leads to exhaustion of assimilate already accumulated in the floret tissues. As a result the optimum modified condition in the packed loose flowers minimized weight loss to the minimum possible extent. Our findings got the support from the findings of Sharma et al., ${ }^{12}$ while working on Asiatic hybrid lily cv. Apeldoorn.

\section{Physiological loss in weight (g)}

Table 3 revealed that in cv. Mexican Single, the physiological loss in weight was lower $(0.66 \mathrm{~g})$ with loose flowers stored in 100 micron thick PE bags with $0 \%$ ventilation, followed by loose flowers stored in $75(4.36 \mathrm{~g})$ and $50(9.27 \mathrm{~g})$ micron thick PE bags with 0 ventilation. The higher physiological loss in weight of florets $(94.98 \mathrm{~g}$ ) was recorded with the florets kept in baskets (control treatment). Table 4 revealed that the lower value $(1.75 \mathrm{~g})$ for physiological loss in weight was obtained by the florets stored in 100micron thick PE bags with $0 \%$ ventilation followed by packaging of florets in $75(4.37 \mathrm{~g})$ and $50(4.54 \mathrm{~g})$ micron thick PE bags without ventilation. However, the higher value $(95.90 \mathrm{~g})$ for physiological loss in weight was recorded for the florets kept without any packaging (control treatment). It is clear from Table 5 that in cv. Sikkim Selection, the lower value $(2.38 \mathrm{~g})$ for physiological loss in weight was obtained by the loose flowers kept in 100 micron thick PE bags with $0 \%$ ventilation followed by packaging of florets in $75(6.74 \mathrm{~g})$ and $50(4.35 \mathrm{~g})$ micron thick PE bags with $0 \%$ ventilation. On the other hand, florets without packaging (control treatment) had the higher $(96.14 \mathrm{~g})$ physiological loss in weight. Packaging without ventilation maintains the humidity which in turn, slows down the process of moisture loss and proper balance of carbon di-oxide and oxygen concentrations lowers down the respiration Anzueto \& Rizve ${ }^{13}$ Tuberose florets stored in PE bags of 100 micron thickness recorded the lowest physiological weight. An increase in thickness of PE bags was associated with a reduction 
in permeability of the bags to moisture and air, thereby reducing the physiological loss in weight, which may be due to a reduction in the loss of moisture as well as respiration of the produce Bhullar \& Farmahan. ${ }^{14}$ The results of this study are in close agreement with the findings of Madhaiah \& Reddy., ${ }^{7}$ Nagaraja et al., ${ }^{8}$ in tuberose and Ravi et al., ${ }^{15}$ Karuppaiah et al., ${ }^{4}$ in jasmine.

\section{Freshness index}

The freshness index was calculated observing the physiological condition of the florets at the termination stage of shelf life and found that in all three tuberose cultivars the freshness index remained of the highest grade denoted as A and awarded with 5 points for the florets kept inside of 50, 75 and 100 micron thick PE bags with 1\% ventilation and graded as $\mathrm{B}$ and awarded with 3 points. Whereas, the freshness index recorded for florets stored in 50,75 and 100micron thick PE bags with $2 \%$ ventilation and also kept in open basket as control treatment, were the lowest grade as $\mathrm{C}$ and awarded with 1 point each (Tables3-5).

\section{Shelf life (day)}

Tables 3-5 revealed that the higher shelf life of florets was recorded when florets were stored in 50, 75 and 100 micron thick PE bags without ventilation (5 day each in cv. Mexican Single and Sikkim Selection and 6, 5, and 5 day, respectively in cv. Prajwal). On the other hand, the lower shelf life (3 day in all cultivars) was obtained in control treatment. Shelf life was retained beyond 6 day in cv. Prajwal under 100 micron thick PE bags packaging without ventilation might be due to more stored food in the floral organs, as shelf life of the flowers is a function of stored food as well. Our findings are in close conformity with findings of Majumdar et al., ${ }^{16}$ in tuberose. Better freshness and longer shelf life were shown when florets were packed in polyethylene of 100 micron thickness with no ventilation, which might be due the fact that the moisture retentive nature of polyethylene packaging material prevents moisture loss and increase the relative humidity inside the packed flowers. This helps to maintain the turgidity of flowers by retaining the moisture apart from lack of photosynthesis. When moisture loss is minimized using polyethylene as packaging material, there will be better maintenance of appearance and extended shelf life of these flowers. Similar results on increase of freshness and extended shelf life of loose flowers due to polyethylene packaging without ventilation have been reported my Madaiah \& Reddy ${ }^{7}$ Nagaraja et al., ${ }^{8}$ in Polianthes tuberosa and Karuppaiah $^{4}$ in Jasminum sambac.

\section{Acknowledgments}

First author acknowledges the receipt of Junior Research Fellowship from Post Graduate School of ICAR -Indian Agricultural Research Institute, New Delhi during his M.Sc. programme. The authors gratefully acknowledge the Director, ICAR-Directorate of Floricultural Research, New Delhi, Heads of Division of Floriculture and Landscaping and Plant Physiology and Incharge, Centre for Protected Cultivation Technology, ICAR- Indian Agricultural Research Institute, New Delhi for providing required facilities for carrying out the research work.

\section{Conflicts of interest}

The Author declares that there is no conflict of interest.

\section{References}

1. Singh KP, Kadam GB, Jyothi R. Production Manual on Tuberose (Polinathes tuberosa Linn.).DFR Extension Bulletin No. 1. Published by Director ICAR-Directorate of Floricultural Resaerch, New Delhi; 2010:1-28.

2. Nowak J, Goszcynska DM, Rudnicki RM. Storage of cut flowers and ornamental plants: Present status and future prospects. Postharvest News Information. 1991;2:255-260.

3. Bhattacharjee SK. Packaging fresh cut flowers. Indian Horticulture. 1997;41:23-27.

4. Karuppaiah P, Kumar, Rajkumar SR. Effect of different packaging behavior and shelf life of jasmine (Jasminum sambac). International Journal of Agricultural Sciences. 2006;2(2):447-449.

5. Premchand GS, Sangroka, T Ogatta. Cell membrane stability as indicators of drought tolerance as affected by applied nitrogen in soyabean. Journal of Agricultural Sciences. 1990;115:63-66.

6. Sairam RK. Effect of moisture stress on physiological activities of two contrasting wheat genotypes. Indian Journal of Experimental Boiology. 1994;32:584-593.

7. Madaiah D, Reddy TV. Influence of polyethylene packaging on the postharvest life of tuberose (cv.Single) florets. Karnataka Journal of Agricultural Sciences. 1994;7(2):154-157.

8. Nagaraja GS, Gowda JVN, Farooqi AA. Shelf life of tuberose flowers as influenced by packaging and ventilation. Karnataka Journal of Agricultural Sciences.1999;12(1-4):239-242.

9. Nirmala S, Reddy, TV. Shelf life of jasmine (Jasminum sambac) flowers as influenced by packaging and ventilation. Mysore Journal of Agricultural Sciences. 1993;27:272-276.

10. Kumari S, Singh KP, Arora A. Screening of cultivars of cut tuberose (Polianthes tuberos $\mathrm{L}$.) flowers for longer vase life on the basis of membrane stability index. Progressive Horticulture. 2013;45(1):164-168.

11. Thamavaiselvi SP, Jawaharlal M, Ganga M et al. Packaging technology for long term storage of jasmine (Jasminum sambac Ait.) flowers. Journal of Ornamental Horticulture. 2010;13(3):171-181.

12. Sharma BP, Beshir, HM Dilta. Effect of various wrapping material and storage durations on post harvest life of Asiatic hybrid lily cv. 'Apeldoorn'. $4^{\text {th }}$ National symposium on "Scenario of Agriculture in Changing Climatic Conditions". 2008:69-74.

13. Anzueto GR, Rizve SSH. Individual packaging of apples for shelf life extension. Journal of Food Science. 1985;50(4):897-900.

14. Bhullar JS, Farmohan HL. Studies on the ripening and storage behaviour of safeda guava (Psidium guajava). Indian Food Packer. 1980;34:5-7.

15. Ravi G, Gopinath G, Ravi MV. Influence of preservative chemicals with or without polyethylene packaging on postharvest behaviour of Jasmine (Jasminum auriculatum Vahl. and Jasminum grandiflorum Linn.) flowers. Mysore Journal of Agricultural Sciences. 2004;38(4):562-532.

16. Majumdar J, Singh KP, Sellam P, et al. Effect of various chemicals with packaging and storage on tuberose (Polianthes tuberosa L.). HortFlora Research Spectrum. 2014;3(2):138-141. 